\title{
Saccharpiscinols A-C: Flavans with Potential Anti-Inflammatory Activities from One Actinobacteria Saccharomonospora piscinae
}

\author{
Yung-Shun Su ${ }^{1,2}$, Jih-Jung Chen ${ }^{3,4}$, Ming-Jen Cheng ${ }^{5, *}$, Chee-Yin Chai ${ }^{1,6}$, Aij-Lie Kwan ${ }^{1,7,8, *}$, \\ Jheng-Cian Huang ${ }^{9}$ and Yueh-Hsiung Kuo $4,9,10,11, *$
}

check for updates

Citation: Su, Y.-S.; Chen, J.-J.; Cheng, M.-J.; Chai, C.-Y.; Kwan, A.-L.;

Huang, J.-C.; Kuo, Y.-H.

Saccharpiscinols A-C: Flavans with

Potential Anti-Inflammatory

Activities from One Actinobacteria Saccharomonospora piscinae. Molecules 2021, 26, 4909. https://doi.org/ $10.3390 /$ molecules26164909

Academic Editors: Francesco Epifano and Luisella Verotta

Received: 3 July 2021

Accepted: 9 August 2021

Published: 13 August 2021

Publisher's Note: MDPI stays neutral with regard to jurisdictional claims in published maps and institutional affiliations.

Copyright: (c) 2021 by the authors. Licensee MDPI, Basel, Switzerland. This article is an open access article distributed under the terms and conditions of the Creative Commons Attribution (CC BY) license (https:/ / creativecommons.org/licenses/by/ $4.0 /)$.
1 Graduate Institute of Medicine, College of Medicine, Kaohsiung Medical University (KMU), Kaohsiung 807, Taiwan; mariussu@gmail.com (Y.-S.S.); ccjtsai@yahoo.com (C.-Y.C.)

2 Department of Dermatology, Kaohsiung Medical University Chung-Ho Memorial Hospital, Kaohsiung 807, Taiwan

3 Department of Pharmacy, School of Pharmaceutical Sciences, National Yang Ming Chiao Tung University (NYCU), Taipei 112, Taiwan; jjungchen@nycu.edu.tw

4 Department of Medical Research, China Medical University Hospital, Taichung 404, Taiwan

5 Bioresource Collection and Research Center (BCRC), Food Industry Research and Development Institute (FIRDI), Hsinchu 300, Taiwan

6 Department of Pathology, Kaohsiung Medical University Chung-Ho Memorial Hospital, Kaohsiung 807, Taiwan

7 Ph.D. Program in Environmental and Occupational Medicine, College of Medicine, Kaohsiung Medical University and National Health Research Institutes, Kaohsiung 807, Taiwan

8 Department of Neurosurgery, Kaohsiung Medical University Chung-Ho Memorial Hospital, Kaohsiung 807, Taiwan

9 Department of Chemistry, National Taiwan University, Taipei 106, Taiwan; huangjc2007@gmail.com

10 Department of Biotechnology, Asia University, Taichung 413, Taiwan

11 Department of Chinese Pharmaceutical Sciences and Chinese Medicine Resources, College of Pharmacy, China Medical University, Taichung 404, Taiwan

* Correspondence: chengfirdi@gmail.com (M.-J.C.); aijliekwan@yahoo.com.tw (A.-L.K.); yhkuo800@gmail.com (Y.-H.K.)

Abstract: Phytochemical investigation and chromatographic separation of extracts from the actinobacteria strain Saccharomonospora piscinae that was isolated from dried fishpond sediment of Kouhu township, in the south of Taiwan, led to the isolation of three new compounds, saccharpiscinols A-C (1-3, respectively), and three new natural products, namely $(2 S)-5,7,3^{\prime}, 4^{\prime}$-tetrahydroxy-6,8dimethylflavanone (4), methyl-4-hydroxy-2-methoxy-6-methylbenzoate (5), and ( \pm )-7-acetyl-4,8dihydroxy-6-methyl-1-tetralone (6). Compounds 4-6 were reported before as synthesized products, herein, they are reported from nature for the first time. The structures of the new compounds were unambiguously elucidated on the basis of extensive spectroscopic data analysis (1D- and 2D-NMR, MS, and UV) and comparison with literature data. The effect of some isolates on the inhibition of NO production in lipopolysaccharide-activated RAW 264.7 murine macrophages was evaluated. Saccharpiscinol A showed inhibitory activities against LPS-induced NO production.

Keywords: Saccharomonospora piscinae; pseudonocardiaceae; actinobacteria; secondary metabolites; NO inhibition

\section{Introduction}

Actinobacteria are widely distributed in nature, and they are very useful in the pharmaceutical industry due to their seemingly unlimited capacity to produce secondary metabolites with diverse chemical structures and biological activities [1-3]. They are gram positive, free-living saprophytic bacteria that are found widely distributed in soil, water, and colonizing plants. Actinobacteria inhabitants have been identified as one of the major groups of the soil population [2,3], which may vary with the soil type. In the process of 
investigation on the diversity of cultivable actinobacteria associated with soil from Taiwan, we isolated a strain named $06168 \mathrm{H}-1^{\mathrm{T}}$, which was isolated from a fishpond sediment sample collected from the southern area of Taiwan and had a unique morphology [4]. This strain was determined to be Saccharomonospora piscinae (Family: Pseudonocardiaceae), based on their phenotypic and genotypic data [4]. In order to find new bioactive compounds, the rare genera in this group have been identified and studied, including the genus Saccharomonospora, which is a genus of bacteria that was only discovered by Nonomura and Ohara, and contained 12 species until now [4]. Saccharomonospora strains are widely distributed in nature, including in soil, compost, plant bodies, marine sediments, sponges, and other environments. Therefore, in addition to mesophilic bacteria, there are also thermophilic strains. The spores of some thermophilic strains (Saccharomonospora viridis) can cause allergic pneumonia (farmer's lung disease). In addition, research reports indicate that strains of this genus can decompose many natural or synthetic compounds, such as polyester, rice straw, mushroom compost, food waste compost, protein, and starch. S. piscinae was isolated from the bottom of the southern fishpond. The colony is blue and performs aerobic growth. The aerial hyphae can produce non-moving short spore chains. It has high salt tolerance and is a salt-tolerant strain. More specialised physiological characteristics can produce special metabolites. It belongs to a special environment strain and is worthy of further investigation and study of its metabolites. However, investigation on the secondary metabolite of Saccharomonospora sp. is still very limited.

Nitric oxide (NO) is a mediator in the inflammatory response involved in host defense. In our effort to search for structurally interesting and bioactive natural products from microbes, we had isolated and identified over 300 microbial strains from Formosan plants and special environment research materials, and the crude EtOAc and $\mathrm{BuOH}$ extracts from those were screened for their inhibitory activity on lipopolysaccharide (LPS)-induced nitric oxide (NO) release production in RAW 264.7 murine macrophages.

In the course of our search for potential diverse secondary metabolites from natural microbial sources, and to further understand the minor metabolites of the genus Saccharomonospora, we examined the EtOAc extract of S. piscinae, which showed rich metabolites according to the fingerprint analysis and inhibitory activity on LPS-induced NO release in RAW 264.7 murine macrophages, as determined by our primary screening (approximately 95\% inhibition at a concentration of $10 \mu \mathrm{g} / \mathrm{mL}$ ). Investigation of the bioactive metabolites of the active EtOAc extract from the microbe S. piscinae, fermented by solid rice medium, was investigated. The metabolites investigation guided by the HPLC profile analysis and 1D NMR spectra prescreening led to the isolation of three new metabolites, saccharpiscinols A-C (1-3, respectively), and three metabolites isolated for the first time from nature sources, $(2 S)-5,7,3^{\prime}, 4^{\prime}$-tetrahydroxy-6,8-dimethylflavanone (4), methyl-4-hydroxy-2-methoxy-6-methylbenzoate (5), and ( \pm )-7-acetyl-4,8-dihydroxy-6methyl-1-tetralone (6).The structures of these isolates were established by means of spectral experiments. The isolation, structural elucidation, and inhibitory effects of some isolates on nitric oxide (NO) production by RAW 264.7 macrophages are described herein.

\section{Results}

\subsection{Structure Elucidation of Compounds}

Compound 1 was obtained as oil (Figure 1). The molecular formula, $\mathrm{C}_{17} \mathrm{H}_{18} \mathrm{O}_{5}$, was determined by electron impact (EI) $\left([\mathrm{M}]^{+}, m / z\right.$ 302) and high-resolution (HR) mass spectrometry. The UV absorptions at 230 and $283 \mathrm{~nm}$ suggested the presence of a flavonoid skeleton [5]. The IR spectrum showed a broad band of $\mathrm{OH}$ absorption at $3340 \mathrm{~cm}^{-1}$ and aromatic absorptions at 1609 and $1510 \mathrm{~cm}^{-1}$. The ${ }^{1} \mathrm{H}$ NMR data of 1 showed the resonances of a group of $\mathrm{ABX}$ aromatic protons $\left[\delta_{\mathrm{H}} 6.97\left(\mathrm{~d}, J=2.0 \mathrm{~Hz}, \mathrm{H}-2^{\prime}\right), 6.89(\mathrm{dd}, J=8.3,2.0 \mathrm{~Hz}\right.$, H-6 $\left.\left.6^{\prime}\right), 6.82\left(\mathrm{~d}, J=8.3 \mathrm{~Hz}, \mathrm{H}-5^{\prime}\right)\right]$, two aromatic singlet protons at $\delta_{\mathrm{H}} 6.52(\mathrm{~s}, \mathrm{H}-5)$ and $6.49(\mathrm{~s}$, $\mathrm{H}-8)$, four mutually-coupling aliphatic protons $\left[\delta_{\mathrm{H}} 2.85(\mathrm{ddd}, J=16.0,11.0,6.0 \mathrm{~Hz}, \mathrm{H}-4 \mathrm{a})\right.$, 2.66 (ddd, $J=16.0,5.0,3.6 \mathrm{~Hz}, \mathrm{H}-4 \mathrm{~b}), 2.12(\mathrm{~m}, \mathrm{H}-3 \mathrm{a}), 2.04$ (m, H-3b)] in ring C, two methoxyl signals at $\delta_{\mathrm{H}} 3.81,3.87$ (each $3 \mathrm{H}, \mathrm{s}, \mathrm{OMe}-6$ and $4^{\prime}$ ), and two active hydrogens at $\delta_{\mathrm{H}} 5.60$ 
$(1 \mathrm{H}, \mathrm{brs})$ and $5.74(1 \mathrm{H}, \mathrm{brs})$. The ${ }^{1} \mathrm{H}-{ }^{1} \mathrm{H}$ COSY experiment of $\mathbf{1}$ revealed two spin systems of $\mathrm{H}-2 / \mathrm{CH}_{2-} 3 / \mathrm{CH}_{2-} 4$ and $\mathrm{H}-5^{\prime} / \mathrm{H}-6^{\prime}$, which further confirmed the presence of resonances attributed to aliphatic protons belonging to the $\mathrm{C}$ ring, and aromatic resonances attributed to protons belonging to the $\mathrm{B}$ rings of flavan moieties. The ${ }^{13} \mathrm{C}$ NMR data (see physical data) showed 17 carbon resonances, comprising 12 olefinic carbons, two methylene carbons $\left(\delta_{C} 24.7\right.$ and 30.0), two methoxyl carbons $\left(\delta_{C} 56.1\right.$ and 56.5), and an oxygenated methane carbon $\left(\delta_{C} 77.2\right)$. Analysis of the ${ }^{1} \mathrm{H}$ and ${ }^{13} \mathrm{C}$ NMR data of $\mathbf{1}$ (see physical data) exhibited a very close structural resemblance to (2S)-7-hydroxy-6-methoxyflavan [6], except for the replacement of the $\mathrm{H}-4^{\prime}$ and $\mathrm{H}-3^{\prime}\left[\delta_{\mathrm{H}} 7.2-7.4\left(2 \mathrm{H}, \mathrm{m}, \mathrm{H}-3^{\prime}\right.\right.$ and $\left.\mathrm{H}-4^{\prime}\right)$ and $128.4\left(\mathrm{C}-3^{\prime}\right), 127.7$ $\left(\mathrm{C}-4^{\prime}\right)$ ] groups in (2S)-7-hydroxy-6-methoxyflavan by a methoxy group $\left[\delta_{\mathrm{H}} 3.87(3 \mathrm{H}, \mathrm{s})\right]$ at $\mathrm{C}-4^{\prime}$ and an $\mathrm{OH}$ group $\left[\delta_{\mathrm{H}} 5.60(1 \mathrm{H}, \mathrm{brs})\right]$ at $\mathrm{C}-3^{\prime}$ in 1 . In the HMBC experiment, the cross-peaks from OH-7 to C-7/C-8, from OH-3' to C-2', from the C-6-methyoxyl protons to C-6, and from OMe- $4^{\prime}$ to C- $4^{\prime}$, placed the methoxyl groups at C- 6 and $4^{\prime}$, and the hydroxy groups at C-7 and $3^{\prime}$, respectively (Figure 2). The absolute configuration of the stereogenic center C-2 in $\mathbf{1}$ was corroborated by optical activity measurement. Compound $\mathbf{1}$ exhibited a negative optical-rotation value $\left([\alpha]_{\mathrm{D}}^{25}-24\left(c=0.02, \mathrm{CHCl}_{3}\right)\right)$, indicating $(S)$-configuration at C-2 in comparison with the reported data of natural flavan analogues [5-9]. The above assignments were further confirmed by a NOESY experiment (Figure 3). Based on the above data, it can be determined that compound $\mathbf{1}$ is (2S)-7,3'-dihydroxy-6,4'-dimethoxyflavan.<smiles>COc1ccc([C@@H]2CCc3cc(OC)c(O)cc3O2)cc1O</smiles><smiles>COc1ccc2c(c1)O[C@@H](c1ccc(O)cc1O)CC2</smiles>

3<smiles>CC(=O)c1c(C)cc2c(c1O)C(=O)CCC2O</smiles><smiles>COc1cc2c(c(C)c1OC)O[C@@H](c1cc(O)c(OC)c(O)c1)CC2</smiles>

2<smiles>Cc1c(O)c(C)c2c(c1O)C(=O)C[C@@H](c1ccc(O)c(O)c1)O2</smiles>

4<smiles>COc1cc(O)cc(C)c1C(C)=O</smiles>

6

Figure 1. Compounds 1-6, isolated from Saccharomonospora piscinae BCRC 16893. 


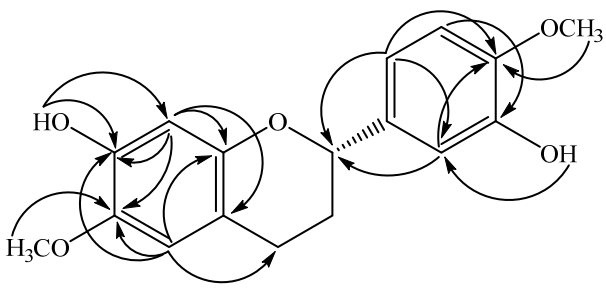

1

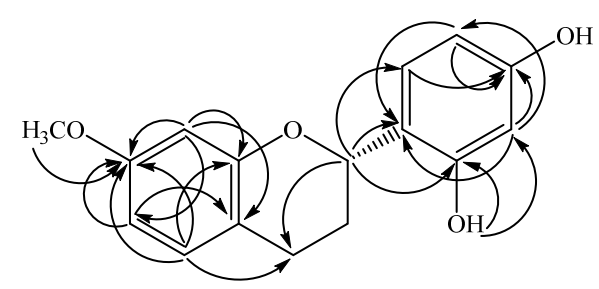

3

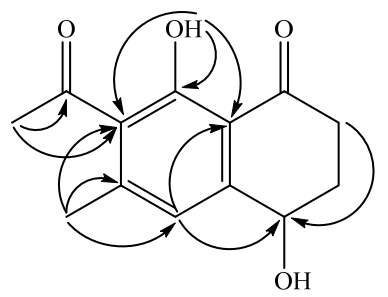

5

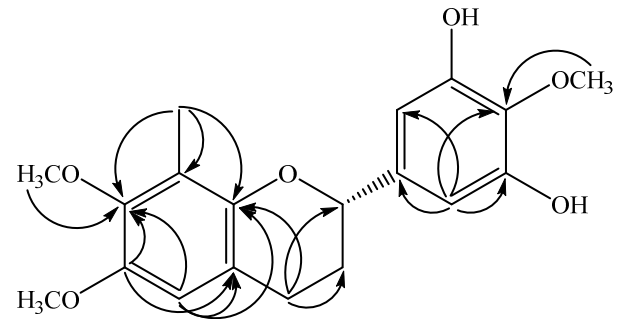

2

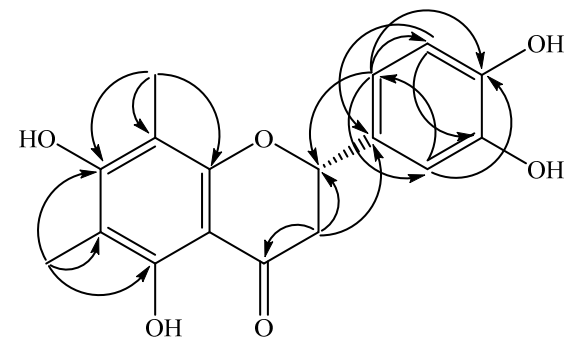

4

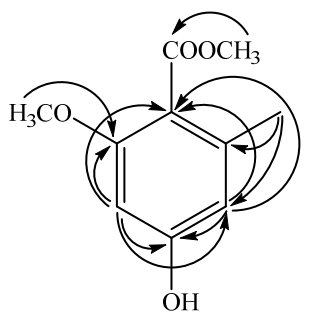

6

Figure 2. Key HMBC $(\rightarrow)$ correlations of 1-6.

Compound 2 was isolated as oil $\left([\alpha]_{D}^{25}-15\left(c=0.02, \mathrm{CHCl}_{3}\right)\right)$. The molecular formula of $\mathrm{C}_{18} \mathrm{H}_{20} \mathrm{O}_{5}$ was established by HR and EI-mass spectrometry ([M] $\left.{ }^{+}, m / z 316\right)$. UV absorption at 231 and $278 \mathrm{~nm}$ indicated the presence of a flavan moiety [4]. The IR spectrum exhibited a hydroxyl absorption at $3423 \mathrm{~cm}^{-1}$ and an aromatic nucleus $\left(1600,1500 \mathrm{~cm}^{-1}\right)$. Detailed analysis of the 1D- and 2D-NMR spectra revealed that 2 was a flavonoid derivative [5], very similar to that of (-)-4'-hydroxy-7-methoxy-8-methylflavan [10], except that a 2methoxybenzene-1,3-diol moiety $\left[\left(\delta_{\mathrm{H}} 3.95\left(3 \mathrm{H}, \mathrm{s}, \mathrm{OCH}_{3-} 4^{\prime}\right), 6.57\left(2 \mathrm{H}, \mathrm{s}, \mathrm{H}-2^{\prime}, 6^{\prime}\right) ; \delta_{\mathrm{C}} 61.1\right.\right.$ $\left(\mathrm{OMe}-4^{\prime}\right), 105.5\left(\mathrm{C}-2^{\prime}\right.$ and $\left.\left.6^{\prime}\right), 133.7\left(\mathrm{C}-1^{\prime}\right), 139.3\left(\mathrm{C}-4^{\prime}\right), 148.8\left(\mathrm{C}-3^{\prime}\right)\right]$ in 2 replaced a 4-phenol moiety $\left[\delta_{\mathrm{H}} 7.32\left(2 \mathrm{H}, \mathrm{d}, J=8.8 \mathrm{~Hz}, \mathrm{C}-2^{\prime}, 6^{\prime}\right)\right.$ and $6.94\left(2 \mathrm{H}, \mathrm{d}, J=8.8 \mathrm{~Hz}, \mathrm{C}-3^{\prime}, 5^{\prime}\right)$ and $\delta_{\mathrm{C}} 155.2$ $\left.\left(\mathrm{C}-4^{\prime}\right), 129.9\left(\mathrm{C}-1^{\prime}\right), 127.6\left(\mathrm{C}-2^{\prime}, 6^{\prime}\right), 115.3\left(\mathrm{C}-3^{\prime}, 5^{\prime}\right)\right]$ in the C-2 position in (-)-4'-hydroxy7-methoxy-8-methylflavan [10]. The location of one of the methoxy groups at C-7 and the Me group at $\mathrm{C}-8$ were inferred from the HMBC correlations of the methoxy protons with C-7, H-5 with C-7, and H-6 with C-8 (Figure 2). The remaining methoxy group at $\mathrm{C}-4^{\prime}$, and two hydroxyl groups at $\mathrm{C}-3^{\prime}$ and $5^{\prime}$ were deduced from the HMBC correlations from $\mathrm{OCH}_{3} 4^{\prime}$ to $\mathrm{C}-4^{\prime}$, and from the aromatic protons $\left(\mathrm{H}-2^{\prime}\right)$ to $\mathrm{C}-2,1^{\prime}, 3^{\prime}, 4^{\prime}$, and $6^{\prime}$ (Figure 2). The levorotatory optical activity $\left([\alpha]_{\mathrm{D}}^{24}-15\left(c=0.02, \mathrm{CHCl}_{3}\right)\right)$ once again indicated the stereochemistry of $C-2$ as $2 S$ [5-8]. Taken together, the structure of compound 2 was assigned as (2S)-3', $5^{\prime}$-dihydroxy-7, $4^{\prime}$-dimethoxy-8-methylflavan.

Compound 3 was isolated as optically active oil with $[\alpha]_{\mathrm{D}}^{25}-21\left(c=0.01, \mathrm{CHCl}_{3}\right)$. The EI-mass spectrum afforded the positive ion at $m / z 272[\mathrm{M}]^{+}$, implying a molecular formula of $\mathrm{C}_{16} \mathrm{H}_{16} \mathrm{O}_{4}$. This was confirmed by the HREI-mass spectrum ([M] ${ }^{+}$found 272.1047 , calcd 
272.1049). The UV absorptions ( 232 and $283 \mathrm{~nm}$ ) were similar to those of (-)-4'-hydroxy7-methoxy-8-methylflavan [10] and were characteristic of the flavan skeleton. The IR spectrum showed absorptions due to a hydroxyl group $\left(3428 \mathrm{~cm}^{-1}\right)$ and an aromatic ring (1626 and $1457 \mathrm{~cm}^{-1}$ ). The ${ }^{1} \mathrm{H}$ NMR data of 3 (see physical data) contained the following resonances: a methoxy signal at $\delta_{\mathrm{H}} 3.73(\mathrm{~s})$, two $\mathrm{ABX}$-spin-coupling system with $\delta_{\mathrm{H}} 6.44$ $(\mathrm{d}, J=2.4 \mathrm{~Hz}, \mathrm{H}-8), 6.50$ (dd, $J=8.4,2.4 \mathrm{~Hz}, \mathrm{H}-6), 6.98$ (d, $J=8.4 \mathrm{~Hz}, \mathrm{H}-5), 6.37$ (dd, $\left.J=8.4,2.4 \mathrm{~Hz}, \mathrm{H}-5^{\prime}\right), 6.97\left(\mathrm{~d}, J=8.4 \mathrm{~Hz}, \mathrm{H}-6^{\prime}\right), 6.40\left(\mathrm{~d}, J=2.4 \mathrm{~Hz}, \mathrm{H}-3^{\prime}\right)$, one oxymethine at $\delta_{\mathrm{H}} 5.11(\mathrm{dd}, J=10.0,2.4 \mathrm{~Hz})$, two methylenes at $\delta_{\mathrm{H}} 2.14-2.28\left(\mathrm{~m}, \mathrm{CH}_{2-} 3\right), 2.93(\mathrm{ddd}$, $J=16.0,12.0,7.2 \mathrm{~Hz}, \mathrm{H}-4 \beta), 2.79$ (ddd, $J=16.0,5.2,2.4 \mathrm{~Hz}, \mathrm{H}-4 \alpha)$, and two active hydrogens at $\delta_{\mathrm{H}} 7.02(1 \mathrm{H}$, brs $)$ and $5.25(1 \mathrm{H}$, brs $)$. The NMR data of 3 were found to be similar to those of (2S)-2', 4'-dihydroxy-7-methoxy-8-methylflavan [11], and the apparent difference was the replacement of an aromatic singlet proton $\left(\delta_{\mathrm{H}} 6.44\right)$ at $\mathrm{C}-8$ in 3 by a Me singlet at C-8 in (2S)-2' $2^{\prime} 4^{\prime}$-dihydroxy-7-methoxy-8-methylflavan. This was supported by the HMBC correlations between $\mathrm{H}-8\left(\delta_{\mathrm{H}} 6.44\right)$ and $\mathrm{C}-6\left(\delta_{\mathrm{C}} 10.3\right), \mathrm{C}-7\left(\delta_{\mathrm{C}} 158.4\right), \mathrm{C}-9\left(\delta_{\mathrm{C}} 153.8\right)$, and $\mathrm{C}-10\left(\delta_{\mathrm{C}} 113.8\right)$, and the NOESY correlations between $\mathrm{H}-8\left(\delta_{\mathrm{H}} 6.44\right)$ and $\mathrm{OCH}_{3-} 7\left(\delta_{\mathrm{H}}\right.$ 3.73). With the aid of $1 \mathrm{D}$ and $2 \mathrm{D}$ NMR experiments, all the ${ }^{1} \mathrm{H}$ and ${ }^{13} \mathrm{C}$ NMR data were completely assigned. In addition, the negative $[\alpha]_{\mathrm{D}}^{25}-21\left(c=0.01, \mathrm{CHCl}_{3}\right)$ value indicated that $C-2$ was in $S$ configuration, which was supported by comparison of the $[\alpha]_{D}$ value of 3 with (2S)-2', $4^{\prime}$-dihydroxy-7-methoxy-8-methylflavan $[5-9,11]$. Therefore, the structure of 3 was established as (2S)-2', $4^{\prime}$-dihydroxy-7-methoxyflavan.

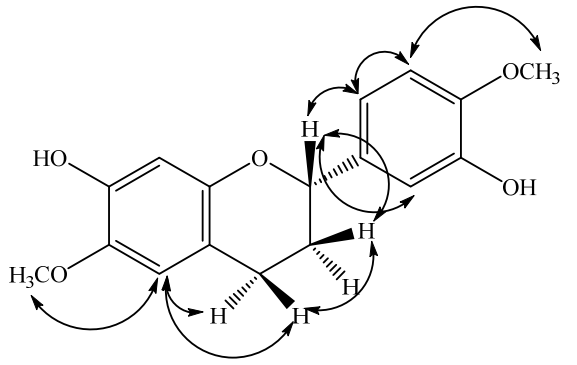

1

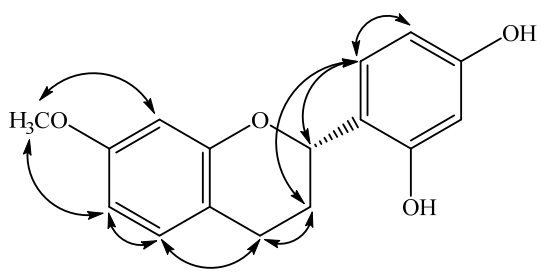

3

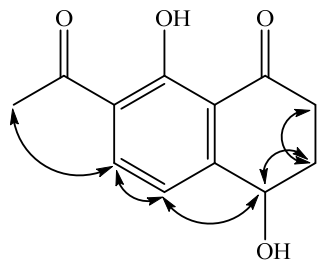

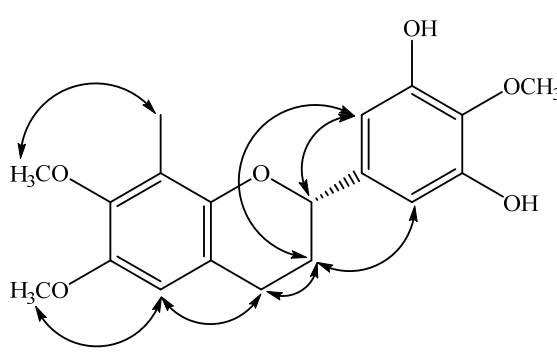

2

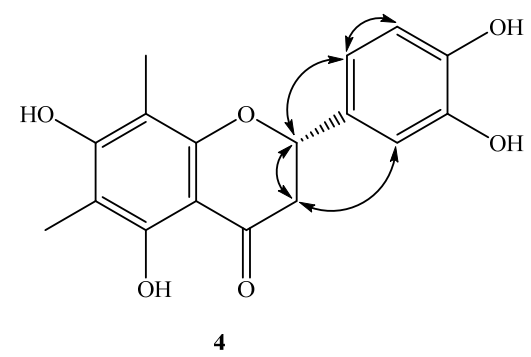<smiles>CC(=O)c1c(O)c2c3c(O)c1OC3CCC2</smiles>

6

Figure 3. Major NOESY $(\leftrightarrow)$ contacts of 1-6. 
Compound 4 was obtained as yellow syrup $\left([\alpha]_{\mathrm{D}}^{25}-22\left(c=0.014, \mathrm{CHCl}_{3}\right)\right)$. The molecular formula was determined as $\mathrm{C}_{17} \mathrm{H}_{16} \mathrm{O}_{6}$ on the basis of the $[\mathrm{M}]^{+}$peak at $m / z$ 316.0945 (calcd. 316.0947 for $\left.\mathrm{C}_{17} \mathrm{H}_{16} \mathrm{O}_{6}\right)$ in its HR-EI-MS. The UV absorptions $\left(\lambda_{\max } 231\right.$, $291 \mathrm{~nm}$ ) confirmed the presence of a flavonoid nucleus [5]. The IR spectrum showed typical absorption bands of hydroxyl and carbonyl groups at 3394 and $1721 \mathrm{~cm}^{-1}$, respectively. The ${ }^{1} \mathrm{H}$ and ${ }^{13} \mathrm{C}$ NMR spectra of 4 are quite similar to those of (2S)-farrerol [12], which suggested that compound 4 has a flavanone structure. Comparing the ${ }^{1} \mathrm{H}$ and ${ }^{13} \mathrm{C}$ NMR spectra of compound 4 with those of (2S)-farrerol, it was presumed that an aromatic proton at $\mathrm{C}^{-3^{\prime}}$ of (2S)-farrerol was substituted with an $\mathrm{OH}$ moiety in 4 , suggested from an $\mathrm{ABX}$ pattern system $\left[\delta_{\mathrm{H}} 6.79\left(\mathrm{brs}, \mathrm{H}-2^{\prime}\right.\right.$ and $\left.5^{\prime}\right), 6.93\left(1 \mathrm{H}, \mathrm{s}, \mathrm{H}-6^{\prime}\right) ; \delta_{\mathrm{C}} 114.6\left(\mathrm{C}-6^{\prime}\right), 116.2(\mathrm{C}-$ $\left.\left.5^{\prime}\right), 119.0\left(\mathrm{C}-2^{\prime}\right), 146.5\left(\mathrm{C}-3^{\prime}\right), 146.7\left(\mathrm{C}-4^{\prime}\right)\right]$ in the B ring which were confirmed by HMBC correlations (Figure 2). Based on these data, the structure of compound 4 was defined as shown, and the compound was named (2S)-5,7,3', $4^{\prime}$-tetrahydroxy-6,8-dimethylflavanone. This is the first time that compound 4 has been isolated from a natural source, although it had previously been synthesized [13].

Compound 5 was identified by comparison with literature data of 7-acetyl-4R,8dihydroxy-6-methyl-1-tetralone [13] but showed a zero optical activity with $[\alpha]_{\mathrm{D}}^{24} \pm 0$ $\left(c=0.01, \mathrm{CHCl}_{3}\right)$. Isolate 6 showed zero optical activity with $[\alpha]_{\mathrm{D}}^{25} \pm 0\left(c=0.01, \mathrm{CHCl}_{3}\right)$, and by reference to (+)-7-acetyl-4R,8-dihydroxy-6-methyl-1-tetralone [13], the configuration of 10 at C-4 was proposed as being in the (R/S)-form. Thus, the isolation of $( \pm)-7-$ acetyl-4R,8-dihydroxy-6-methyl-1-tetralone (5) as a natural product is also reported for the first time. Compound 5 was identified by comparison with literature data of 7-acetyl$4 R, 8$-dihydroxy-6-methyl-1-tetralone [14] but showed a zero optical activity with $[\alpha]_{\mathrm{D}}^{25} \pm 0$ $\left(c=0.01, \mathrm{CHCl}_{3}\right)$. Isolate 5 showed zero optical activity with $[\alpha]_{\mathrm{D}}^{25} \pm 0\left(c=0.01, \mathrm{CHCl}_{3}\right)$, and by reference to (+)-7-acetyl-4R,8-dihydroxy-6-methyl-1-tetralone [13], the configuration of 10 at $C-4$ was proposed as being in the $(R / S)$-form. Thus, the isolation of $( \pm)-7$ acetyl-4R,8-dihydroxy-6-methyl-1-tetralone (5) as a natural product is also reported for the first time.

Compound 6 was obtained as gum. Its molecular formula, $\mathrm{C}_{10} \mathrm{H}_{12} \mathrm{O}_{4}$, was deduced from a $[\mathrm{M}]^{+}$peak at $m / z 196.0733$ in its HREIMS spectrum (calcd. 196.0736 for $\mathrm{C}_{10} \mathrm{H}_{12} \mathrm{O}_{4}$ ). There are 10 carbon signals in the ${ }^{13} \mathrm{C}$ NMR spectrum, including one ester $\mathrm{C}=\mathrm{O}$ at $\delta_{\mathrm{C}}$ 168.0, one methyl group at $\delta_{C} 19.7$, two methoxyls at $\delta_{C} 51.7$ and 55.9 , and six aromatic carbon atoms with one deshielded signal at $\delta_{C}$ 159.6. The ${ }^{1} \mathrm{H}$ and ${ }^{13} \mathrm{C}$ NMR spectra of 5 are quite similar to those of methyl-2,4-dihydroxy-6-methyl benzoate, which suggested that compound 5 has a benzenoid structure. Comparing the ${ }^{1} \mathrm{H}$ and ${ }^{13} \mathrm{C}$ NMR spectra of compound 5 with those of the similar analogue, methyl-2,4-dihydroxy-6-methyl benzoate, it was presumed that a hydroxyl group $\left[\delta_{\mathrm{H}} 11.60(1 \mathrm{H}, \mathrm{s}, \mathrm{OH}-2) ; \delta_{\mathrm{C}} 163.24(\mathrm{C}-2)\right]$ at $\mathrm{C}-2$ of methyl-2,4-dihydroxy-6-methyl benzoate was substituted with a methoxy moiety in 8 from the signals at $\left[\delta_{\mathrm{H}} 3.72(3 \mathrm{H}, \mathrm{s}, \mathrm{OMe}-2) ; \delta_{\mathrm{C}} 55.9(\mathrm{OMe}-2)\right]$, which were confirmed by $\mathrm{HMBC}$ correlations. The HMBC correlations of OMe-2/C-2' and Me-6/C-6, 1 and 5 determined the positions of methoxyl and methyl groups, which was confirmed by the correlations between OMe-2/H-3 and Me-6/H-5 in the NOESY spectrum (Figure 3). Finally, the NMR data were identical to those of methyl-4-hydroxy-2-methoxy-6-methylbenzoate, which has been obtained synthetically [15]. This is the first time $\mathbf{6}$ has been isolated from a nature source.

\section{Analysis EtOAc Crude Extracts of Compounds by HPLC}

The EtOAc extracts from the rice fermentation of the actinobacteria, S. piscinae was analyzed by HPLC and detection by UV spectroscopy (waters 600 pump and 996 photodiode array detector) on an Inertsil ODS-3 column, $5 \mu \mathrm{m}, 250 \mathrm{~mm} \times 4.6 \mathrm{~mm}$ i.d. (GL Sciences, Tokyo, Japan) using gradient of (A) water containing $0.1 \%$ phosphoric acid and (B) acetonitrile: 0-50 min, $90-50 \%$ A; 50-80 min, 50\% A-100\% B; flow $1 \mathrm{~mL} / \mathrm{min}$. Chromatograms were recorded at wavelength $237 \mathrm{~nm}$. (Figure 4). 


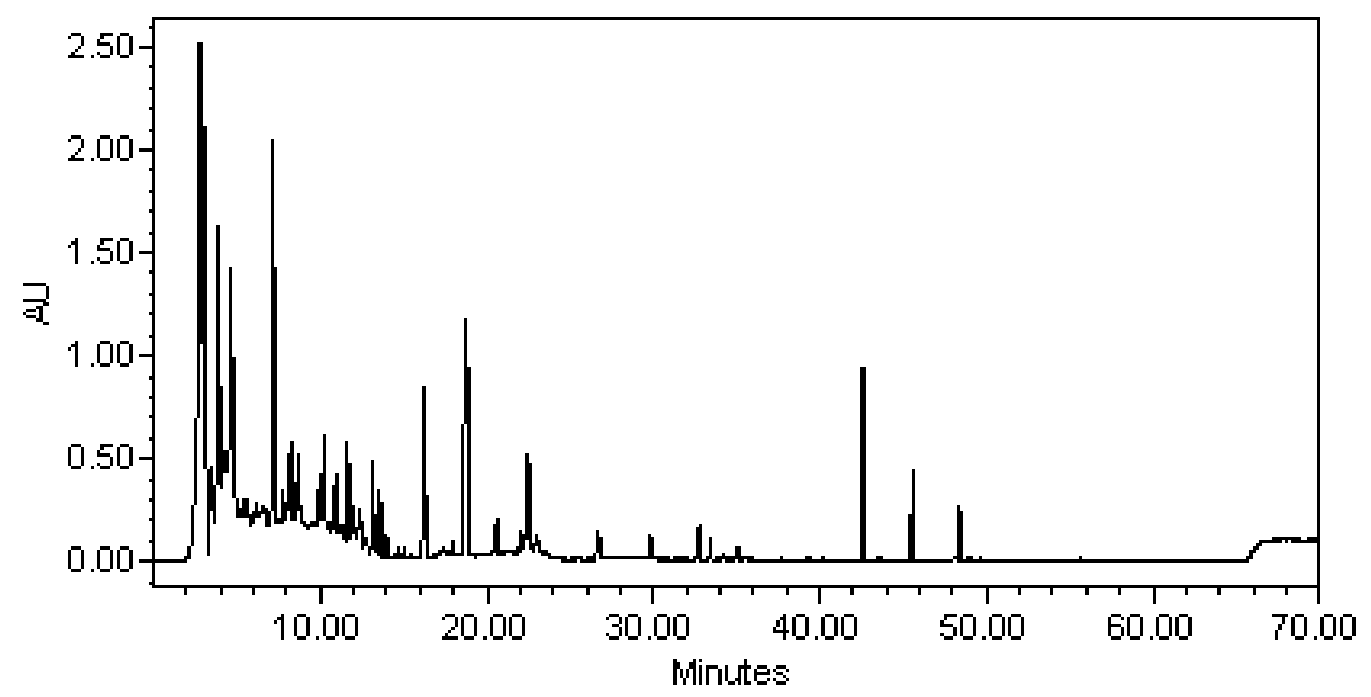

Figure 4. HPLC fingerprints of EtOAc extracts from the rice fermentation of the actinobacteria, Saccharomonospora piscinae, $\lambda=237 \mathrm{~nm}$.

\subsection{Biological Studies}

Due to the small quantity of isolated compounds (5 and 6 ), we evaluated the inhibitory effects of saccharpiscinols A-C (1-3, respectively) and (2S)-5,7, $3^{\prime}, 4^{\prime}$-tetrahydroxy6,8-dimethylflavanone (4) on the production of NO induced by LPS (Table 1). They showed potent inhibition with $\mathrm{IC}_{50}$ values between 12.5 to $21.8 \mu \mathrm{M}$ against lipopolysaccharide (LPS)-induced nitric oxide (NO) generation. The high cell viability $(>80 \%)$ indicated that the inhibitory activity of LPS-induced nitrite production by compounds $\mathbf{1}$ and $\mathbf{2}\left(\mathrm{IC}_{50}\right.$ value: $12.5 \mu \mathrm{M}$ and $18.0 \mu \mathrm{M}$ ) did not result from its cytotoxicity. Compounds 3 and 4 ( IC $_{50}$ value: $21.8 \mu \mathrm{M}$ and $20.0 \mu \mathrm{M}$ ) also showed inhibition of the NO production of macrophages, but the low cell viability $(<80 \%)$ suggested the possibility of cytotoxicity.

Table 1. Effects of compounds (1-4) on LPS-induced NO production and cell viability in RAW 264.7 macrophages.

\begin{tabular}{ccc}
\hline Compound & IC $_{\mathbf{5 0}}$ & Cell Viability \\
\hline $\mathbf{1}$ & Nitrite $(\boldsymbol{\mu M})$ & $\mathbf{( \% \text { Control) }}$ \\
$\mathbf{2}$ & $12.5 \pm 0.2^{*}$ & $91.1 \pm 4.2$ \\
$\mathbf{3}$ & $18.0 \pm 0.3^{*}$ & $82.2 \pm 3.2^{\#}$ \\
$\mathbf{4}$ & $21.8 \pm 0.5^{*}$ & $76.3 \pm 5.4^{\#}$ \\
Quercetin & $20.0 \pm 1.5^{*}$ & $68.2 \pm 3.3^{\#}$ \\
\hline
\end{tabular}

The RAW 264.7 cells were incubated with compounds in the presence of LPS $(1 \mu \mathrm{g} / \mathrm{mL})$. The medium was harvested $24 \mathrm{~h}$ later and assayed for nitrite production. NO release was measured by using the Griess reagent. The cell viability was evaluated with the MTT assay. The results are presented as a percentage of the control value obtained from non-treated cells. Values are expressed as mean \pm SD of three individual experiments, performed in triplicate. * Statistically significant difference compared to LPS-activated cells $(p<0.05)$. ${ }^{\#}$ Statistically significant difference compared to untreated cells $(p<0.05)$.

\section{Materials and Methods}

\subsection{General Experimental Procedures}

TLC: silica gel $60 \mathrm{~F}_{254}$ precoated plates (Merck). Column chromatography (CC): silica gel 60 (70-230 or 230-400 mesh, Merck) and Spherical C18 100A Reversed Phase Silica Gel (RP-18) (particle size: $20-40 \mu \mathrm{m})$ (Silicycle). HPLC: Spherical C18 column $(250 \times 10 \mathrm{~mm}$, $5 \mu \mathrm{m})$ (Waters); LDC-Analytical-III apparatus. UV Spectra: Jasco UV-240 spectrophotometer; $\lambda_{\max }(\log \varepsilon)$ in $\mathrm{nm}$. Optical rotation: Jasco DIP-370 polarimeter; in $\mathrm{CHCl}_{3}$. IR Spectra: Perkin-Elmer-2000 FT-IR spectrophotometer; $v$ in $\mathrm{cm}^{-1} .{ }^{1} \mathrm{H}-,{ }^{13} \mathrm{C}$ - and $2 \mathrm{D}-\mathrm{NMR}$ spectra: 
Varian-Mercury-400 and Varian-Unity-Plus-400 spectrometers; $\delta$ in ppm relative to $\mathrm{Me}_{4} \mathrm{Si}, J$ in Hz. ESI and HRESIMS: Bruker APEX-II mass spectrometer; in $m / z$.

\subsubsection{Microorganism}

Saccharomonospora piscinae $\left(06168 \mathrm{H}-1^{\mathrm{T}}\right)$ was used throughout this study, and deposited at the Bioresource Collection and Research Center (BCRC), Food Industry Research and Development Institute (FIRDI). This actinobacteria was identified by M. T.

\subsubsection{Cultivation and Preparation of the Fungal Strain}

The actinobacteria, Saccharomonospora piscinae, $\left(06168 \mathrm{H}-1^{\mathrm{T}}\right)$, was isolated from dried fishpond sediment from the Kouhu township, in the south of Taiwan. The sample of fishpond sediment was dried at room temperature for 7 days. The sample suspension $(100 \mu \mathrm{L})$ was plated on modified Sabouraud glucose agar (SGA; $7.5 \mathrm{~g}$ casamino acid, $10.0 \mathrm{~g}$ yeast extract, $20.0 \mathrm{~g} \mathrm{MgSO} 4 \cdot 7 \mathrm{H}_{2} \mathrm{O}, 3.0 \mathrm{~g}$ trisodium citrate $2 \mathrm{H}_{2} \mathrm{O}, 2.0 \mathrm{~g} \mathrm{KCl}, 34.0 \mathrm{~g} \mathrm{NaCl}$, $10.0 \mu \mathrm{g} \mathrm{Fe}{ }^{2+}, 18.0 \mathrm{~g}$ agar, 1.01 distilled water, $\mathrm{pH}$ adjusted to 7.4) and incubated at $30^{\circ} \mathrm{C}$ for 4 weeks. The spores or mycelia suspension were harvested with $20 \%(v / v)$ glycerol and stored at $-20^{\circ} \mathrm{C}$.

The actinobacteria, Saccharomonospora piscinae, $\left(06168 \mathrm{H}-1^{\mathrm{T}}\right)$, was maintained on Sabouraud glucose agar (SGA) and the strain was cultured on potato dextrose agar slants at $30{ }^{\circ} \mathrm{C}$ for 7 days, and then the spores were harvested by sterile water. The spores $\left(5 \times 10^{5}\right)$ were seeded into $500 \mathrm{~mL}$ shake flasks containing $50 \mathrm{~mL} \mathrm{CM+YM}$ (Sabouraud glucose agar, SGA; $7.5 \mathrm{~g}$ casamino acid, $10.0 \mathrm{~g}$ yeast extract, $20.0 \mathrm{~g} \mathrm{MgSO} 4 \cdot 7 \mathrm{H}_{2} \mathrm{O}, 3.0 \mathrm{~g}$ trisodium citrate $2 \mathrm{H}_{2} \mathrm{O}, 2.0 \mathrm{~g} \mathrm{KCl}, 34.0 \mathrm{~g} \mathrm{NaCl}, 10.0 \mu \mathrm{g} \mathrm{Fe}{ }^{2+}, 18.0 \mathrm{~g}$ agar, $1.0 \mathrm{~L}$ distilled water, $\mathrm{pH}$ adjusted to 7.4 ) and cultivated with shaking $(150 \mathrm{rpm})$ at $30^{\circ} \mathrm{C}$ for 5 days. After the mycelium enrichment step, an inoculum mixing $100 \mathrm{~mL}$ mycelium broth and $100 \mathrm{~mL}$ $\mathrm{CM}+\mathrm{YM}$ medium was inoculated into plastic boxes $(25 \mathrm{~cm} \times 30 \mathrm{~cm})$ containing $1.3 \mathrm{~kg}$ sterile rice and cultivated at $30^{\circ} \mathrm{C}$ for producing rice, and the abovementioned $\mathrm{CM}+\mathrm{YM}$ medium was added to maintain the growth. After 21 days of cultivation, the rice was harvested, and used as a sample for further extraction.

\subsubsection{Isolation and Characterization of Secondary Metabolites}

The rice fermentation was extracted five times with an equal volume of EtOAc. The combined EtOAc layers were evaporated to dryness under reduced pressure to give an EtOAc extract ( $12 \mathrm{~g})$ which was subjected to silica gel column chromatography (CC) (petroleum ether-EtOAc $v / v$, gradient; from 10:1 to 0:1 to generate seven fractions (Frs. 1-7). Fr. 2 was isolated by CC on silica gel eluted with hexane-EtOAc (from 5:1 to 1:1) to afford four subfractions (Fr. 2.1-2.4). Subfraction Fr. 2.3 was further purified by semipreparative $\mathrm{HPLC}\left(\mathrm{CH}_{3} \mathrm{CN} / \mathrm{H}_{2} \mathrm{O}, 40: 60 \mathrm{v} / v\right)$ to obtain $6(1.2 \mathrm{mg})$. Subfraction Fr. 2.4 was further separated by HPLC $\left(\mathrm{CH}_{3} \mathrm{CN} / \mathrm{H}_{2} \mathrm{O}, 40: 60 v / v\right)$ to obtain $5(1.51 \mathrm{mg})$. Compound 3 $(10.4 \mathrm{mg})$ was preferentially precipitated from Fr. 3. Fr. 5 was separated into 13 subfractions (Fr. 5-1-Fr. 5-13) by silica gel column chromatography eluted with a step gradient of petroleum ether-EtOAc (from 1:0 to 0:1, $v / v$ ). Fr. 5-2 was subjected to analytical RP-HPLC $\left(85 \% \mathrm{MeOH}-\mathrm{H}_{2} \mathrm{O}\right)$ to obtain $4(3.2 \mathrm{mg})$. Fr. $5-5$ was also purified by analytical RP-HPLC $\left(77.5 \% \mathrm{MeOH}-\mathrm{H}_{2} \mathrm{O}\right)$ to afford compounds $\mathbf{1}(3.2 \mathrm{mg})$ and $\mathbf{2}(10.4 \mathrm{mg})$.

Saccharpiscinol A (1): oil; [ $\alpha] 25 \mathrm{D}-24\left(c\right.$ 0.01, $\left.\mathrm{CHCl}_{3}\right)$; UV (MeOH): 230 (4.14), 283.0 (3.85) nm; IR (Neat): $3400(\mathrm{OH}), 1609,1510$ (aromatic $\mathrm{C}=\mathrm{C}) \mathrm{cm}^{-1} ;{ }^{1} \mathrm{H}$ NMR $(400 \mathrm{MHz}$, $\left.\mathrm{CDCl}_{3}\right): \delta_{\mathrm{H}} 6.97\left(1 \mathrm{H}, \mathrm{d}, J=2.0 \mathrm{~Hz}, \mathrm{H}-2^{\prime}\right), 6.89\left(1 \mathrm{H}, \mathrm{dd}, J=8.3,2.0 \mathrm{~Hz}, \mathrm{H}-6^{\prime}\right), 6.82(1 \mathrm{H}, \mathrm{d}, J=$ $\left.8.3 \mathrm{~Hz}, \mathrm{H}-5^{\prime}\right), 6.52(1 \mathrm{H}, \mathrm{s}, \mathrm{H}-5), 6.49(1 \mathrm{H}, \mathrm{s}, \mathrm{H}-8), 5.60(1 \mathrm{H}$, br.s, OH-3'), $5.47(1 \mathrm{H}$, br.s, OH-7), $4.88(1 \mathrm{H}, \mathrm{dd}, J=10.0,2.4 \mathrm{~Hz}, \mathrm{H}-2), 3.87\left(3 \mathrm{H}, \mathrm{s}, \mathrm{OCH}_{3} 4^{\prime}\right), 3.81\left(3 \mathrm{H}, \mathrm{s}, \mathrm{OCH}_{3}-6\right), 2.85(1 \mathrm{H}$, ddd, $J=16.0,11.0,6.0 \mathrm{~Hz}, \mathrm{H}-2 \beta), 2.66(1 \mathrm{H}, \mathrm{ddd}, J=16.0,5.0,3.6 \mathrm{~Hz}, \mathrm{H}-2 \alpha), 2.12(1 \mathrm{H}, \mathrm{m}$, $\mathrm{H}-3 \beta), 2.04(1 \mathrm{H}, \mathrm{m}, \mathrm{H}-3 \alpha) ;{ }^{13} \mathrm{C}$ NMR $\left(100 \mathrm{MHz}, \mathrm{CDCl}_{3}\right): \delta_{\mathrm{c}} 149.2(\mathrm{C}-9), 146.2\left(\mathrm{C}-4^{\prime}\right), 145.6$ (C-3'), 144.8 (C-7), 140.8 (C-6), $134.7\left(\mathrm{C}-1^{\prime}\right), 112.2\left(\mathrm{C}-2^{\prime}\right), 112.5$ (C-10), 117.8 (C-6'), 111.4 (C-5), 110.5 (C-5'), 103.5 (C-8), 77.2 (C-2), 56.5 (OMe-6), 56.1 (OMe-6), 24.7 (C-4), 30.0 (C-3); HREIMS $m / z 302.1153$ [M] ${ }^{+}$(calcd. for $\mathrm{C}_{17} \mathrm{H}_{18} \mathrm{O}_{5}, 302.1154$ ). 
Saccharpiscinol B (2): oil; $[\alpha] 25 \mathrm{D}=-15$ ( c 0.01, $\left.\mathrm{CHCl}_{3}\right)$; UV (MeOH): 230 (4.14), 283.0 (3.85) nm; IR (Neat): $3400(\mathrm{OH}), 1609,1510$ (aromatic $\mathrm{C}=\mathrm{C}) \mathrm{cm}^{-1} ;{ }^{1} \mathrm{H}$ NMR $(400 \mathrm{MHz}$, $\left.\mathrm{CDCl}_{3}\right): \delta_{\mathrm{H}} 6.84(1 \mathrm{H}, \mathrm{d}, J=8.3 \mathrm{~Hz}, \mathrm{H}-5), 6.57\left(1 \mathrm{H}, \mathrm{s}, \mathrm{H}-6^{\prime}\right), 6.43(1 \mathrm{H}, \mathrm{d}, J=8.3 \mathrm{~Hz}, \mathrm{H}-6), 4.92$ $(1 \mathrm{H}, \mathrm{dd}, J=10.0,2.1 \mathrm{~Hz}, \mathrm{H}-2), 3.95\left(3 \mathrm{H}, \mathrm{s}, \mathrm{OCH}_{3-} 4^{\prime}\right), 3.85(3 \mathrm{H}, \mathrm{s}, \mathrm{OMe}-7), 2.87(1 \mathrm{H}, \mathrm{ddd}, J=$ 16.0, 10.5, 8.3 Hz, H-4ß), 2.70 (1H, ddd, $J=16.0,8.8,4.5 \mathrm{~Hz}, \mathrm{H}-4 \alpha), 2.15(1 \mathrm{H}, \mathrm{m}, \mathrm{H}-3 \beta), 2.10$ (3H, s, Me-8), $1.93(1 \mathrm{H}, \mathrm{m}, \mathrm{H}-3 \alpha) ;{ }^{13} \mathrm{C} \mathrm{NMR}\left(100 \mathrm{MHz}, \mathrm{CDCl}_{3}\right): \delta_{\mathrm{c}} 156.7(\mathrm{C}-7), 153.2(\mathrm{C}-9)$, $148.8\left(\mathrm{C}-3^{\prime}\right.$ and $\left.5^{\prime}\right), 139.3\left(\mathrm{C}-4^{\prime}\right), 133.7\left(\mathrm{C}-1^{\prime}\right), 126.1(\mathrm{C}-5), 114.2(\mathrm{C}-10), 113.8(\mathrm{C}-8), 105.5\left(\mathrm{C}-2^{\prime}\right.$ and $\left.6^{\prime}\right), 103.1(\mathrm{C}-6), 77.2(\mathrm{C}-2), 61.1\left(\mathrm{OMe}^{\prime}\right)$, 55.8 (OMe-7), 30.0 (C-3), 24.6 (C-4), 8.7 (Me-8); HREIMS $m / z 316.1310[\mathrm{M}]^{+}$(calcd. for $\mathrm{C}_{18} \mathrm{H}_{20} \mathrm{O}_{5}, 316.1308$ ).

Saccharpiscinol C (3): oil; $[\alpha] 25 \mathrm{D}=-21.0$ (c 0.01, $\left.\mathrm{CHCl}_{3}\right)$; UV (MeOH): 232 (4.08), 283 (3.69) nm; IR (Neat): $3428(\mathrm{OH}), 1626$ (aromatic C=C) $\mathrm{cm}^{-1} ;{ }^{1} \mathrm{H}$ NMR $\left(400 \mathrm{MHz}, \mathrm{CDCl}_{3}\right)$ : $\delta_{\mathrm{H}} 7.02\left(1 \mathrm{H}\right.$. br.s, OH-2'), $6.98(1 \mathrm{H}, \mathrm{d}, J=8.4 \mathrm{~Hz}, \mathrm{H}-5), 6.97\left(1 \mathrm{H}, \mathrm{d}, J=8.4 \mathrm{~Hz}, \mathrm{H}-6^{\prime}\right), 6.50$ $(1 \mathrm{H}, \mathrm{dd}, J=8.4,2.4 \mathrm{~Hz}, \mathrm{H}-6), 6.44(1 \mathrm{H}, \mathrm{d}, J=2.4 \mathrm{~Hz}, \mathrm{H}-8), 6.40\left(1 \mathrm{H}, \mathrm{d}, J=2.4 \mathrm{~Hz}, \mathrm{H}-3^{\prime}\right), 6.37$ $\left(1 \mathrm{H}, \mathrm{dd}, J=8.4,2.4 \mathrm{~Hz}, \mathrm{H}-5^{\prime}\right), 5.25\left(1 \mathrm{H}\right.$, br.s, $\left.\mathrm{OH}-2^{\prime}\right), 5.11(1 \mathrm{H}, \mathrm{dd}, J=10.0,2.4 \mathrm{~Hz}, \mathrm{H}-2)$, 3.73 (3H, s, OMe-7), $2.93(\mathrm{ddd}, J=16.0,12.0,7.2 \mathrm{~Hz}, \mathrm{H}-4 \beta), 2.79$ (1H, ddd, $J=16.0,5.2$, $2.4 \mathrm{~Hz}, \mathrm{H}-4 \alpha), 2.14-2.28(2 \mathrm{H}, \mathrm{m}, \mathrm{H}-3 \alpha$ and $\beta) ;{ }^{13} \mathrm{C}$ NMR $\left(100 \mathrm{MHz}, \mathrm{CDCl}_{3}\right): \delta_{\mathrm{c}} 158.4(\mathrm{C}-7)$, $156.1\left(\mathrm{C}-2^{\prime}\right), 155.6\left(\mathrm{C}-4^{\prime}\right), 153.8$ (C-9), 129.9 (C-5), $127.7\left(\mathrm{C}-6^{\prime}\right), 108.3(\mathrm{C}-6), 117.7\left(\mathrm{C}-1^{\prime}\right), 113.8$

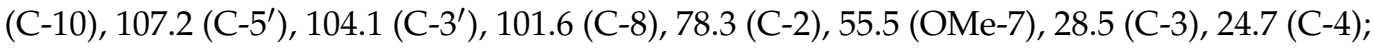
EIMS (70 eV) m/z (\%): $272\left(\left[\mathrm{M}^{+}, 100\right), 150\right.$ (42), 137 (90), 101 (20); HREIMS m/z 272.1047 $[\mathrm{M}]^{+}$(calcd. for $\mathrm{C}_{16} \mathrm{H}_{16} \mathrm{O}_{4}, 272.1049$ ).

The compound, (2S)-5,7,3',4'-Tetrahydroxy-6,8-dimethylflavanone (4): oil; [ $\alpha] 25$ $\mathrm{D}=-22$ (c 0.01, $\left.\mathrm{CHCl}_{3}\right) ; \mathrm{UV}(\mathrm{MeOH}): 231$ (4.44), 291 (4.35) nm; IR (Neat): $3394(\mathrm{OH})$, 1721 (conjugated $\mathrm{C}=\mathrm{O}), 1619,1453$ (aromatic $\mathrm{C}=\mathrm{C}) \mathrm{cm}^{-1},{ }^{1} \mathrm{H} \mathrm{NMR}\left(400 \mathrm{MHz}, \mathrm{CDCl}_{3}\right): \delta_{\mathrm{H}}$ 6.93(1H, s, H-6 $), 6.80(1 \mathrm{H}$, br.s, H-5') $6.79(1 \mathrm{H}$, br.s, H-2' $), 5.24(1 \mathrm{H}, \mathrm{dd}, J=12.5,3.0 \mathrm{~Hz}$, H-2), $3.02(1 \mathrm{H}, \mathrm{dd}, J=16.9,12.5 \mathrm{~Hz}, \mathrm{H}-3 \alpha), 2.71(1 \mathrm{H}, \mathrm{dd}, J=16.9,3.0 \mathrm{~Hz}, \mathrm{H}-3 \beta), 2.00(3 \mathrm{H}$, s, Me-8), $1.99(3 \mathrm{H}, \mathrm{s}, \mathrm{Me}-6) ;{ }^{13} \mathrm{C}$ NMR $\left(100 \mathrm{MHz}, \mathrm{CDCl}_{3}\right): \delta_{\mathrm{c}} 198.4(\mathrm{C}-4), 164.1(\mathrm{C}-7), 160.2$ (C-5), 159.3 (C-9), $146.7\left(\mathrm{C}-4^{\prime}\right), 146.5\left(\mathrm{C}-3^{\prime}\right), 132.2\left(\mathrm{C}-1^{\prime}\right), 119.0\left(\mathrm{C}-2^{\prime}\right), 116.2\left(\mathrm{C}-5^{\prime}\right), 114.6$ $\left(\mathrm{C}-6^{\prime}\right), 104.7$ (C-10), 104.1 (C-6), 103.3 (C-8), 80.0 (C-2), 44.2 (C-3), 8.2 (C-6), 7.4 (Me-8); EIMS (70 eV) m/z (\%): $316[\mathrm{M}]^{+}(100), 286$ (12), 255 (10), 207 (13), 194 (20), 181 (68), 152 (52), 136 (17), 55 (10); HREIMS $m / z 316.0945[\mathrm{M}]^{+}$(calcd. for $\mathrm{C}_{17} \mathrm{H}_{16} \mathrm{O}_{6}, 316.0947$ ).

The compound, $( \pm)$-7-Acetyl-4,8-dihydroxy-6-methyl-1-tetralone (5): oil; $[\alpha]_{\mathrm{D}}^{25} \pm 0(c$ 0.01, $\mathrm{CHCl}_{3}$ ); UV (MeOH): 210 (4.56), 238.0 (4.61), 272.0 (4.40), 336.0 (4.17) nm; IR (Neat): $3428(\mathrm{OH}), 1796(\mathrm{C}=\mathrm{O}), 1626,1552(\operatorname{aromatic} \mathrm{C}=\mathrm{C}) \mathrm{cm}^{-1},{ }^{1} \mathrm{H} \mathrm{NMR}\left(400 \mathrm{MHz}, \mathrm{CDCl}_{3}\right): \delta_{\mathrm{H}}$ $12.78(1 \mathrm{H}, \mathrm{s}, \mathrm{OH}-8), 6.85(1 \mathrm{H}, \mathrm{s}, \mathrm{H}-5), 4.79(1 \mathrm{H}, \mathrm{dd}, J=7.9,3.7 \mathrm{~Hz}, \mathrm{H}-4), 2.88(1 \mathrm{H}, \mathrm{ddd}$, $J=17.8,7.3,4.6 \mathrm{~Hz}, \mathrm{H}-2 \mathrm{eq}), 2.57(1 \mathrm{H}, \mathrm{ddd}, J=17.8,9.1,4.7 \mathrm{~Hz}, \mathrm{H}-2 \mathrm{ax}), 2.50\left(3 \mathrm{H}, \mathrm{s}, \mathrm{CH}_{3-} 11\right)$, $2.28(1 \mathrm{H}, \mathrm{m}, \mathrm{H}-3 \mathrm{eq}), 2.23\left(3 \mathrm{H}, \mathrm{s}, \mathrm{CH}_{3} 6\right), 2.10(1 \mathrm{H}, \mathrm{m}, \mathrm{H}-3 \mathrm{ax}) ;{ }^{13} \mathrm{C} \mathrm{NMR}\left(100 \mathrm{MHz}, \mathrm{CDCl}_{3}\right)$ : $\delta_{\mathrm{c}} 204.2$ (C-11), 203.9 (C-1), 160.0 (C-8), 146.9 (C-10), 145.3 (C-6), 129.7 (C-7), 119.3 (C-5), 113.2 (C-9), 67.3 (C-4), 34.7 (C-2), $32.0\left(\mathrm{CH}_{3-11}\right), 31.2$ (C-3), $20.3\left(\mathrm{CH}_{3-6}\right.$; EIMS (70 eV) m/z (\%): 234 ([M] $\left.]^{+}, 35\right), 219$ (100), 201 (40), 145 (20), 77 (18), 55 (20); HREIMS m/z 234.0889 [M] $^{+}$ (calcd. for $\mathrm{C}_{13} \mathrm{H}_{14} \mathrm{O}_{4}, 234.0892$ ).

Methyl-4-hydroxy-2-methoxy-6-methylbenzoate (6): gum; UV (MeOH): 221.0 (4.15), 253.0 (3.69), 281.0 (3.56) nm; IR (Neat): $3370(\mathrm{OH}), 1701$ (ester $\mathrm{C}=\mathrm{O}), 1604,1454$ (aromatic $\mathrm{C}=\mathrm{C}) \mathrm{cm}^{-1} ;{ }^{1} \mathrm{H}$ NMR $\left(400 \mathrm{MHz} \mathrm{CDCl}_{3}\right): \delta_{\mathrm{H}} 8.57(1 \mathrm{H}$, br.s, $\mathrm{OH}-4), 6.34(1 \mathrm{H}, \mathrm{d}, J=1.8 \mathrm{~Hz}$, H-3) $6.29(1 \mathrm{H}, \mathrm{d}, J=1.8 \mathrm{~Hz}, \mathrm{H}-5), 3.76\left(3 \mathrm{H}, \mathrm{s}, \mathrm{OCH}_{3-} 7\right), 3.72\left(3 \mathrm{H}, \mathrm{s}, \mathrm{OCH}_{3} 2\right), 2.16(3 \mathrm{H}$, $\left.\mathrm{s}, \mathrm{CH}_{3-6}\right) ;{ }^{13} \mathrm{C}$ NMR $\left(100 \mathrm{MHz} \mathrm{CDCl}_{3}\right): \delta_{\mathrm{c}} 168.0(\mathrm{C}-7), 159.2(\mathrm{C}-4), 158.4(\mathrm{C}-2), 137.8(\mathrm{C}-$ 6), 116.0 (C-1), 109.1 (C-5), 97.1 (C-3), $55.9\left(\mathrm{OCH}_{3} 2\right), 51.7\left(\mathrm{OCH}_{3}-7\right), 19.7\left(\mathrm{CH}_{3-} 6\right)$; EIMS $(70 \mathrm{eV}) \mathrm{m} / z(\%): 196\left([\mathrm{M}]^{+}, 32\right), 165(100), 122(10) ;$ HREIMS m/z 196.0733 [M] $^{+}$(calcd. for $^{2}$ $\left.\mathrm{C}_{10} \mathrm{H}_{12} \mathrm{O}_{4}, 196.0736\right)$.

\subsubsection{Determination of NO Production and Cell Viability Assay}

Mouse macrophage cell line (RAW 264.7) was obtained from the Bioresource Collection and Research Center (BCRC 60001) and cultured at $37^{\circ} \mathrm{C}$ in Dulbecco's Modified Eagle's Medium (DMEM) supplemented with 10\% fetal bovine serum (Gibco), $4.5 \mathrm{~g} / \mathrm{L}$ glucose, $4 \mathrm{mM}$ glutamine, penicillin (100 units $/ \mathrm{mL})$, and streptomycin $(100 \mu \mathrm{g} / \mathrm{mL})$ in a humidified 
atmosphere in a $5 \% \mathrm{CO}_{2}$ incubator. The cells were treated with 10,25 , and $50 \mu \mathrm{M}$ of natural products in the presence of $1 \mu \mathrm{g} / \mathrm{mL}$ LPS (lipopolysaccharide, Sigma-Aldrich) for $20 \mathrm{~h}$. The concentration of NO in culture supernatants was determined as nitrite, a major stable product of NO, by a Griess reagent assay [16], and cell viabilities were determined using the MTT assay as described previously [17].

\section{Conclusions}

Under the support of the Ministry of Economic Affairs, the Bioresource Collection and Research Center at the Food Industry Research and Development Institute has been dedicated to the research work on the collection, separation, and preservation of bioresource research in the past few years, and has constructed a complete indigenous strains resource bank in Taiwan. The applicant analyzed the active constituents from it, and obtained more than sixty active new compounds isolated from red yeast rice, endophytes, actinobacteria, and mushrooms, among which many new compounds have anti-cancer and anti-inflammatory effects [18-23].

Actinobacteria have the ability to produce a variety of physiologically active products, so they play a very important role in the food and pharmaceutical industries. Over the years, our team has also separated and collected actinomycetes resources from all over Taiwan and various environments. In addition to common Streptomyces, there are also many rare species of actinobacteria, and there are many new species. Based on the concept of "new species and new compounds", it is expected that special compounds can be found from these new strains. In recent years, studies have also found that these new species of actinobacteria can produce many active secondary metabolites. In order to further explore the efficacy of different strains of actinobacteria and expand the application range of actinomycetes, therefore, this project uses one new species of actinobacteria that has not been studied in the past. This species is cultured, extracted, purified and identified with high-level and highly active anti-inflammatory compounds with solid rice, in order to improve the research of actinobacteria at the country level, and develop health products related to actinobacteria. In summary, we have isolated and characterized three undescribed flavan derivatives, saccharpiscinols A-C, from an actinobacteria strain Saccharomonospora piscinae that was isolated from dried fishpond sediment from the Kouhu township, in the south of Taiwan. The absolute configurations of saccharpiscinols A-C were determined by comparing their optical activities with related derivatives. Saccharpiscinols A and B showed inhibitory activities against LPS-induced NO production. The discovery of flavan derivatives from actinobacteria pointed toward the potential use of endophytic or associated Saccharomonospora piscinae as alternative producers of flavan derivatives. The current results may encourage further investigations on the chemistry and bioactivity of flavan metabolites. These results also suggest that Saccharomonospora has distinct and diverse metabolites that arise under different fermentation conditions and soil-derived collections. It may therefore be possible to find more new bioactive natural products by searching Saccharomonospora species under special eco-environments. For the sake of better understanding the distribution of flavan acid analogs, the actinobacteria of the tilted research material and other special strains are worth examining for the presence of these secondary metabolites.

Supplementary Materials: The following are available online, Figures S1 S7 1D, 2D NMR, and EIMS spectra for 1, Figures S8 S14 1D, 2D NMR, and EIMS spectra for 2, Figures S15 S21 1D, 2D NMR, and EIMS spectra for 3, Figures S22 S28 1D, 2D NMR, and EIMS spectra for 4, Figures S29 S35 1D, 2D NMR, and EIMS spectra for 5, Figures S36 S42 1D, 2D NMR, and EIMS spectra for 6.

Author Contributions: A.-L.K., Y.-H.K. and M.-J.C. designed the research; Y.-S.S. and M.-J.C. performed the research; Y.-S.S. and C.-Y.C. conducted biological assays; Y.-S.S., J.-J.C., J.-C.H. and M.-J.C. helped with structure elucidation; Y.-S.S. and M.-J.C. analyzed the data and wrote the paper. All authors have read and agreed to the published version of the manuscript. 
Funding: This work was kindly supported by the Food Industry Research and Development Institute (FIRDI) and supported by the Ministry of Science and Technology, R.O.C. (MOST-108-2320-B-080-002and 110-2320-B-080-001-).

Institutional Review Board Statement: Not applicable.

Informed Consent Statement: Not applicable.

Data Availability Statement: The data presented in this study are available in the article and Supplementary Materials.

Acknowledgments: The authors thank Min Tseng for her help in strain identification, cultivation and fermentation, and thank Senior Technician Chyi Jia Wang of the Center for Resources, Research and Development (CRRD) of Kaohsiung Medical University for measuring the 2D NMR data. We would like to thank the librarian, Ni Ni Naing, at Universities' Central Library (UCL) for her enthusiasm to provide us with valuable academic references.

Conflicts of Interest: The authors declare no conflict of interest.

Sample Availability: Samples of the compounds are available from the authors.

\section{References}

1. Osada, H. Fascinating bioactive compounds from actinomycetes. Actinomycetologica 1995, 9, 254-262. [CrossRef]

2. Mythili, B.; Ayyappa Das, M.P. Studies on antimicrobial activity of Streptomyces spp. isolates from tea plantation soil. Res. J. Agric. Sci. 2011, 2, 104-106.

3. Kuster, E. The Actinomycetes. In Soil Biology; Burges, A., Raw, F., Eds.; Academic Press: London, UK, 1968 ; pp. 111-124.

4. Tseng, M.; Chiang, W.P.; Liao, H.C.; Hsieh, S.Y.; Yuan, G.F. Saccharomonospora piscinae sp. nov., a novel actinobacterium from fishpond sediment in Taiwan. Int. J. Syst. Evol. Microbiol. 2018, 68, 1418-1422. [CrossRef]

5. Ali, A.; Makboul, M.A.; Attia, A.A.; Ali, D.T. Chromones and flavans from Pancratium maritimum. Phytochemistry 1990, $29,625-627$. [CrossRef]

6. Rezende, L.C.; Juck, D.B.F.; David, J.M.; David, J.P.; Lima, M.V.B.; Lima, L.S.; Alves, C.Q. New flavans isolated from the leaves and stems of Cratylia mollis (Leguminosae). Phytochem. Lett. 2015, 14, 165-169. [CrossRef]

7. Achenbach, H.; Stoecker, M.; Constenla, M.A. Flavonoid and other constituents of Bauhinia manca. Phytochemistry 1988, 27, 1835-1842.

8. Loset, J.D.; Marston, A.; Gupta, M.P.; Hostettmann, K. A methylflavan with free radical scavenging properties from Pancratium littorale. Fitoterapia 2001, 72, 35-39.

9. Masaoud, M.; Ripperger, H. Flavonoids of dragon's blood from Dracaena cinnabari. Phytochemistry 1995, 38, 745-749. [CrossRef]

10. Abd El-Hafiz, M.A.; Ramadan, M.A.; Anton, R. Minor Phenolic Constituents of Crinum augustum. J. Nat. Prod. 1990, 53, 1349-1352. [CrossRef]

11. Tan, B.Q.; Huang, S.S.; Liang, Y.E.; Sun, J.B.; Ma., Y.; Zeng, B.; Lee, S.M.Y.; Lu, J.L. Two new flavans from the roots of Dianella ensifolia (L.) DC. Nat. Prod. Res. 2017, 31, 1561-1565.

12. Youssef, D.T.A.; Ramadan, M.A.; Khalifa, A.A. Acetophenones, a chalcone, a chromone and flavonoids from Pancratium maritimum Phytochemistry 1998, 49, 2579-2583. [CrossRef]

13. Kishimoto, Y. Pharmaceutical studies on ferns. XI. flavonoids of Cyrtomium species (3). Constitution of cyrtominetin and cyrtopterinetin. Chem. Pharm. Bull. 1956, 4, 24-28. [CrossRef] [PubMed]

14. Nhung, L.T.H.; Linh, N.T.T.; Cham, B.T.; Thuy, T.T.; Tam, N.T.; Thien, D.D.; Huong, P.T.M.; Tan, V.M.; Tai, B.H.; Anh, N.T.H. New phenolics from Dianella ensifolia. Nat. Prod. Res. 2019, 1-8. [CrossRef] [PubMed]

15. Elix, J.A.; Lajide, L. Three new tridepsides from the lichen Pseudocyphellaria faveolata. Aust. J. Chem. 1981, 34, 2005-2011. [CrossRef]

16. Gieni, R.S.; Li, Y.; Hay Glass, K.T. Comparison of [3H]thymidine incorporation with MTT- and MTS-based bioassays for human and murine IL-2 and IL-4 analysis. Tetrazolium assays provide markedly enhanced sensitivity. J. Immunol. Methods 1995, 70, 85-93. [CrossRef]

17. Johansson, M.; Kopcke, B.; Anke, H.; Sterner, O. Biologically active secondary metabolites from the ascomycete A111-95. 2. structure elucidation. J. Antibiot. 2002, 55, 104-106. [CrossRef] [PubMed]

18. Cheng, M.J.; Wu, M.D.; Chan, H.Y.; Chang, H.S.; Wu, H.C.; Chen, J.J.; Yuan, G.F.; Weng, J.R.; Chang, C.T.; Lin, H.C. A new azaphilone derivative from the Monascus kaoliang fermented rice. Chem. Nat. Compd. 2019, 55, 79-81. [CrossRef]

19. Wu, H.C.; Cheng, M.J.; Wu, M.D.; Chen, J.J.; Chen, Y.L.; Chang, H.S. Three new constituents from the fungus of monascus purpureus and their anti-inflammatory activity. Phytochem. Lett. 2019, 31, 242-248. [CrossRef]

20. Cheng, M.J.; Wu, M.D.; Su, Y.S.; Chan, H.Y.; Hsieh, S.Y.; Chen, Y.L.; Chen, J.J.; Chou, Y.T.; Hsiao, C.Y.; Wu, H.S. Additional chemical constituents of an endophytic fungus Xylaria papulis. Chem. Nat. Compd. 2019, 55, 340-342. [CrossRef]

21. Feng, K.J.; Cheng, M.J.; Yang, S.H.; Wu, M.D.; Hsieh, S.Y.; Chan, H.Y.; Su, Y.S.; Chou, Y.T.; Chang, H.S. Chemical constituents of the endophytic fungus Ophiocordyceps sobolifera. Chem. Nat. Compd. 2019, 55, 309-312. [CrossRef] 
22. Cheng, M.J.; Wu, M.D.; Wu, H.C.; Chan, H.Y.; Chen, Y.L.; Chang, H.S.; Chen, J.J.; Kuo, Y.H. Benzenoid derivatives and amide constituents of the Monascus sp.-fermented rice. Chem. Nat. Compd. 2019, 55, 787-789. [CrossRef]

23. Wu, H.C.; Chen, J.J.; Wu, M.D.; Cheng, M.J.; Chang, H.S. Identification of new pigments produced by the fermented rice of the fungus Monascus pilosus and their anti-inflammatoryactivity. Phytochem. Lett. 2020, 40, 181-187. [CrossRef] 